\title{
Western equatorial African forest-savanna mosaics: a legacy of late Holocene climatic change?
}

\author{
A. Ngomanda ${ }^{1}$, A. Chepstow-Lusty ${ }^{2}$, M. Makaya ${ }^{3}$, C. Favier ${ }^{2}$, P. Schevin ${ }^{2}$, J. Maley ${ }^{2}$, M. Fontugne ${ }^{4}$, R. Oslisly ${ }^{5}$, and \\ D. Jolly ${ }^{*} \dagger$ \\ ${ }^{1}$ Institut de Recherche en Ecologie Tropicale, IRET/CENAREST, BP. 13354, Libreville, Gabon \\ ${ }^{2}$ Institut des Sciences de l'Evolution de Montpellier, UMR 5554, Université de Montpellier II, Place Eugène Bataillon, cc 61, \\ 34095 Montpellier Cedex 5, France \\ ${ }^{3}$ Université des Sciences et Techniques de Masuku, Département de Géologie, BP. 901, Franceville, Gabon \\ ${ }^{4}$ Laboratoire des Sciences du Climat et de l'Environnement, UMR CEA/CNRS 1572, Domaine du CNRS, 91198 Gif sur \\ Yvette cedex, France \\ ${ }^{5}$ IRD - Cameroun, BP. 1857, Yaoundé, Cameroun \\ * formerly at: Institut des Sciences de l'Evolution de Montpellier, UMR 5554, Université de Montpellier II, Place Eugène \\ Bataillon, cc 61, 34095 Montpellier Cedex 5, France \\ $\dagger$ deceased
}

Received: 27 October 2008 - Published in Clim. Past Discuss.: 9 February 2009

Revised: 12 August 2009 - Accepted: 16 September 2009 - Published: 26 October 2009

\begin{abstract}
Past vegetation and climate changes reconstructed using two pollen records from Lakes Maridor and Nguène, located in the coastal savannas and inland rainforest of Gabon, respectively, provide new insights into the environmental history of western equatorial African rainforests during the last $4500 \mathrm{cal}$ yr BP. These pollen records indicate that the coastal savannas of western equatorial Africa did not exist during the mid-Holocene and instead the region was covered by evergreen rainforests. From ca. 4000 cal yr BP a progressive decline of inland evergreen rainforest, accompanied by the expansion of semi-deciduous rainforest, occurred synchronously with grassland colonisation in the coastal region of Gabon. The contraction of moist evergreen rainforest and the establishment of coastal savannas in Gabon suggest decreasing humidity from ca. $4000 \mathrm{cal} \mathrm{yr} \mathrm{BP.} \mathrm{The}$ marked reduction in evergreen rainforest and subsequent savanna expansion was followed from 2700 cal yr BP by the colonization of secondary forests dominated by the palm, Elaeis guineensis, and the shrub, Alchornea cordifolia (Euphorbiaceae). A return to wetter climatic conditions from about 1400 cal yr BP led to the renewed spread of evergreen
\end{abstract}

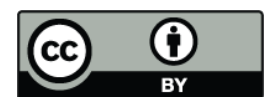

Correspondence to: A. Ngomanda (ngomanda@yahoo.fr) rainforest inland, whereas a forest-savanna mosaic still persists in the coastal region. There is no evidence to suggest that the major environmental changes observed were driven by human impact.

\section{Introduction}

In western equatorial Africa, the tropical lowland rainforest of Gabon is well known for its high biodiversity (Sosef, 1994). This part of the Guineo-Congolian rainforest (White, 1983 ) is today well conserved because of the absence of intensive agricultural activities, coupled with low population densities. However, although the Gabonese rainforest shows a relatively homogeneous aspect, it is included by grass-dominated savannas, most notably at its periphery in the coastal area, or within the forest block (e.g. the forestsavanna mosaic in the Middle Valley of Ogooué, see Fig. 1).

The origin and persistence of these savanna patches, typical of drier environments, remains controversial, as at these equatorial latitudes the current humid conditions favour rainforest development (Aubréville, 1967). A number of ecologists have assumed that the effects of recent human impact (e.g. cultivation, forest logging or savanna fires) can be extrapolated to explain the dynamics of the forest/savanna

Published by Copernicus Publications on behalf of the European Geosciences Union. 


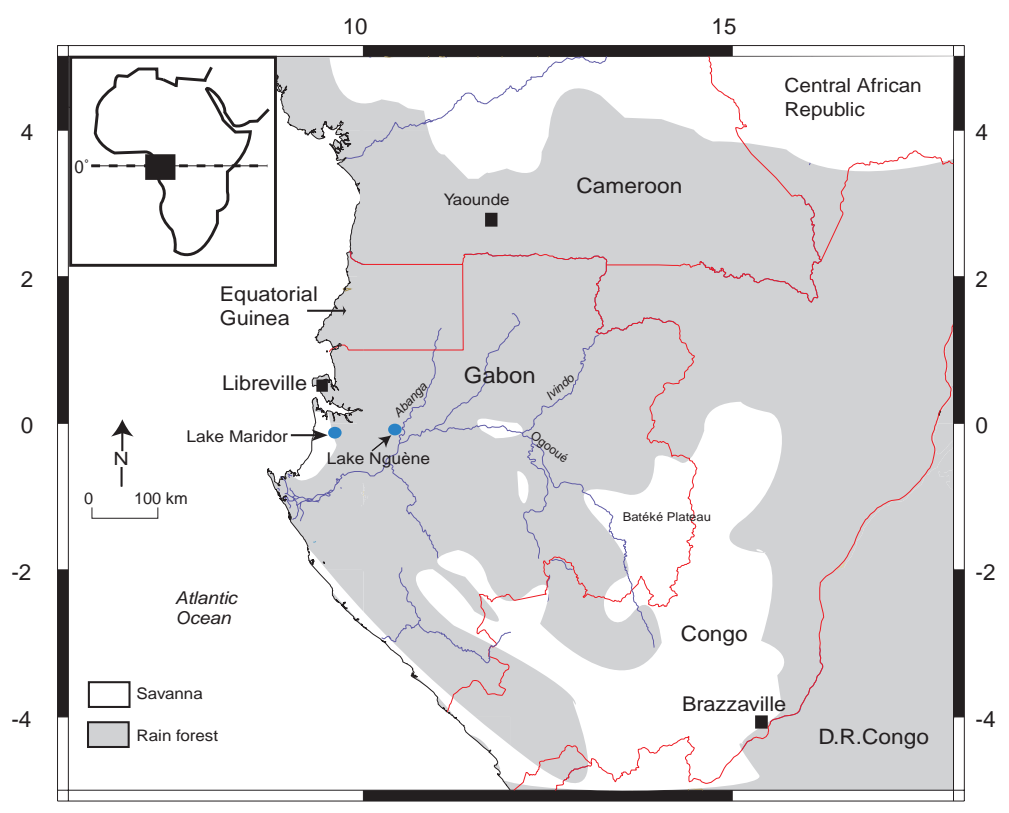

Fig. 1. Simplified vegetation map of Gabon in central Africa and location of Lakes Maridor and Nguène.

ecotone during the past few millennia (Fontes, 1978; White, 1992, 2001; King et al., 1997).

Indirect evidence for a climatic rather than an anthropogenic origin for these savannas is provided by regional palaeoclimatic data from Lakes Barombi-Mbo (Giresse et al., 1994; Maley and Brenac, 1998) and Ossa (Reynaud-Farrera et al., 1996; Wirrmann et al., 2001; Nguetsop et al., 2004; Giresse et al., 2005) in Cameroon, and Lakes Sinnda (Vincens et al., 1998) and Kitina (Elenga et al., 1996) in the Congo, which are situated at the northern and southern limits of the Guineo-Congolian rainforest, respectively. Unlike the savannas formed during the coolest and driest conditions of the Last Glacial Maximum (Maley and Brenac, 1998), which were subsequently recovered by rainforest expansion, palaeoclimatogical data indicate that the late-Holocene savannas correspond with a period of aridity and marked lakelevel reduction. For example, Lake Sinnda became completely dry about $4000 \mathrm{C}^{14} \mathrm{yr}$ BP (Vincens et al., 1998). This aridity produced a sudden contraction of rainforests, followed by a renewed expansion of savannas associated with secondary forests.

Archaeological findings for the same period indicate that Bantu-speaking peoples arrived in Central Africa synchronously as the widespread appearance of savannas and fragmented rainforests (Schwartz, 1992). It has been suggested that human migration from the grasslands of the Nigerian-Cameroonian border into central Africa at the onset of the late-Holocene was favoured by canopy openings in the dense rainforest. The band of small coastal savannas, which today run down from Equatorial Guinea through Gabon to the Congo, may even constitute part of the old migration route (Oslisly, 2001).
Here, we present two new high-resolution pollen records from Gabon, spanning the late Holocene in order to determine the origin, timing and persistence of the forest-savanna mosaic on the coast and within the dense rainforest block inland.

\section{Regional setting}

Lakes Nguène and Maridor are shallow lakes $(\sim 3$ to $5 \mathrm{~m}$ depth) located in the western part of Gabon, at the same equatorial latitude, though in highly contrasting geomorphological and vegetational settings. Lake Nguène is situated on the southern slopes of the Cristal Mounts $\left(0^{\circ} 12^{\prime} \mathrm{S}-\right.$ $10^{\circ} 28^{\prime} \mathrm{E}, 20 \mathrm{~m}$ a.s.l.), approximately $160 \mathrm{~km}$ from the northwest coast of Gabon (Fig. 1). This ancient fluvial depression of the Abanga River has an area of $\sim 6 \mathrm{~km}^{2}$, with large areas of the littoral zone covered by a dense swamp of Cyperaceae (Cyperus papyrus, Killinga sp., Cyperus sp., Eleocharis sp., etc.). In its northern part, the lake basin has an extensive floodplain, with abundant herbaceous plants (Asteraceae, Amaranthaceae, Polygonum sp., etc.), grasses (such as Phragmites sp. and Echinoclora sp.), as well as some flood-tolerant shrubs, particularly Nauclea pobeguinii (Rubiaceae) and Uapaca heudolotii (Euphorbiaceae). On the waterlogged soils of sheltered lake shores, dense hygrophytic vegetation occurs, mainly dominated by shrubs of Alchornea cordifolia (Euphorbiaceae). The natural riparian vegetation of Lake Nguène is dominated by trees belonging to the Caesalpiniaceae family (Anthonota macrophylla, Cynometra sp., Guibourtia sp., etc.). Away from the lake, the Nguène region, located in one of the most species-rich areas 
of western equatorial Africa (Sosef, 1994), supports an evergreen rainforest dominated by Aucoumea klaineana, Dacryodes büettneri (Burseraceae), Desbordesia glaucescens (Irvingiaceae), and Monopetalanthus sp. (Caesalpiniaceae) (Nicolas, 1977; Caballé and Fontes, 1978).

By contrast Lake Maridor $\left(0^{\circ} 10^{\prime} \mathrm{S}-9^{\circ} 21^{\prime} \mathrm{E}\right)$ is located approximately $3 \mathrm{~km}$ from the coast of Gabon. The lake basin, maintained both by direct precipitation, small streams and probably by groundwater infiltration, has a surface area of about $0.25 \mathrm{~km}^{2}$. Its shallow water is partly covered by macrophytes, while a marsh dominated by monocotyledonous herbs and Cyperaceae separate the lake basin from a small Mitragyna ciliata (Rubiaceae) and Uapaca guineensis dominated swamp forest (Christy et al., 1990). This small wetland is surrounded by a forest-savanna mosaic with secondary forests rich in Aucoumea klaineana and low-diversity savannas, mostly consisting of grasses in the tribe Andropogoneae. These secondary forests have been suggested to result from human disturbance of the coastal mature evergreen rainforest, rich in Aucoumea klaineana, Saccoglottis gabonensis (Humiriaceae) and Erismadelphus exsul (Vochysiaceae) (Nicolas, 1977; Caballé and Fontes, 1978; Christy et al., 1990), during the last few centuries, notably by logging. According to Christy et al. (1990), the mature evergreen rainforest today around Lake Maridor represents only 30\% of the original forest cover.

Climatically, these two lakes lie in a humid part of Gabon, with mean annual rainfall ranging from $1916 \mathrm{~mm}$ at Lambaréné, $100 \mathrm{~km}$ south of Lake Nguène, to $2834 \mathrm{~mm}$ at Libreville, $70 \mathrm{~km}$ north of Lake Maridor (period from 1953-1989). Precipitation is seasonal, with a wet season which lasts about nine months (September to May), interspersed by a "short dry season" centred on January with a distinct reduction in rainfall. Temperatures vary little throughout the year, with a range of $20-33^{\circ} \mathrm{C}$; these are lowest during the major dry season (June to September), when cloud cover is almost constant, because of lower sea-surface temperatures in the Gulf of Guinea (Leroux, 1983). Similarly, mean relative humidity also varies little over the year and does not fall below $70 \%$

\section{Materials and methods}

Sediments were collected using a Vibracorer from the central part of Lakes Nguène and Maridor at $2 \mathrm{~m}$ water depth. Using a sampling strategy of 5 and $10 \mathrm{~cm}$ intervals, 55 samples were obtained from core NGUE1 and 58 from core MAR2, respectively. Pollen preparation followed the standard methodology (Faegri and Iversen, 1989): dissolution of the carbonates and silicate with diluted $\mathrm{HCl}(10 \%)$ and cold $\mathrm{HF}(70 \%)$, respectively; removal of colloidal silica with warm diluted $\mathrm{HCl}$, and destruction of humic acids by dilution in $\mathrm{KOH}$ $(10 \%)$ solution. The obtained residue was diluted in glycerol. Identification was based on the reference collection at the Institut des Sciences de l'Evolution de Montpellier (Université
Montpellier II), as well as published pollen images for tropical Africa (Assemien et al., 1974; Ybert, 1979; Bonnefille and Riollet, 1980). Pollen nomenclature follows the African Pollen database (http://medias.obs-mip.fr/apd/). Pollen percentages are based on a sum of at least 600 pollen grains and pteridophyte spores. However, to show a clear representation of the forest component, at least 250 terrestrial pollen grains were counted at each level, excluding Gramineae. These latter, as well as the local marshy herbaceous taxa (Cyperaceae, pteridophytes, Nymphaea, etc.) are excluded from the pollen sum used to express pollen abundance of terrestrial taxa, because their high pollen abundance masks the forest signal.

The chronology of the cores NGUE1 and MAR2 is based on radiocarbon ages determined by a gas proportional counter and AMS methods using samples of bulk organic matter (Table 1). These radiocarbon dates were converted to calendar years using the INTCAL04 calibration curve (Reimer et al., 2004), and a continuous chronology based on the stratigraphically consistent series of dates from each sequence was derived by linear interpolation between the calibrated ages.

\section{Age models and sedimentation rates}

Of the 11 radiocarbon dates from core NGUE1, ten dates are stratigraphically consistent, although two minor dating inversions can be noted. If the base of core NGUE1 is considered as dating from $4780 \mathrm{cal}$ yr BP, two possible chronologies can be derived from the 11 radiocarbon ages (Fig. 2). The first chronology (Fig. 2, dotted line) shows a significant change in the sedimentation rate through the gley-mud at $187 \mathrm{~cm}$. However, this change is neither associated with lithology nor with marked variation in the sand content, and hence suggests a regional environmental shift. Thus, the $3310 \pm 40{ }^{14} \mathrm{C}$ yr BP date, stratigraphically and sedimentologically anomalous, is probably caused by allochtonous inputs or reworked organic matter. In contrast, the second chronology (Fig. 2, solid line), based on nine radiocarbon dates, clearly shows that changes in accumulation rates are systematically synchronous either with increasing sand content or with lithological variation. For example, between $2540 \pm 400^{14} \mathrm{C}$ yr BP and $2429 \pm 40{ }^{14} \mathrm{C} \mathrm{yr} \mathrm{BP}$, the accumulation rate is very high $(0.20 \mathrm{~cm} / \mathrm{yr})$ and contemporaneous with high sand content (between 2 and 6\%) suggesting an active erosive phase or strong stream transport. In the light of these stratigraphical and lithological considerations, the age-model illustrated by the solid line has been retained.

Core MAR2 shows a sedimentary discontinuity around $405-400 \mathrm{~cm}$ with the A2 horizon of the podzolic soil missing (Fig. 3), which suggests a hiatus of several hundred years. This hiatus, however, does not appear in the MAR1 test-core as this core shows a $20 \mathrm{~cm}$-thick A2 horizon in the podzolic soil, inferring that the sediment break in the MAR2 core was not caused by the drying up of Lake Maridor. Above the 
Table 1. Radiocarbon dates of bulk organic matter from cores MAR2 and NGUE1 of Lakes Maridor and Nguène, respectively. All radiocarbon dates were calibrated using the program INTCAL04 (Reimer et al., 2004).

\begin{tabular}{lrrrlr}
\hline $\begin{array}{l}\text { Core } \\
\text { Number }\end{array}$ & $\begin{array}{r}\text { Depth } \\
(\mathrm{cm})\end{array}$ & ${ }^{14}$ C age BP & $\begin{array}{r}\text { Calendar age }(\mathrm{yr} \text { BP }) \\
\text { and range }(2 \delta)\end{array}$ & Materiel dated & Laboratory code \\
\hline Maridor-2 (423) & 25 & $1490 \pm 60$ & $1360(1299-1518)$ & Bulk & BETA 195417 (AMS) \\
& 97 & $3230 \pm 40$ & $3435(3377-3557)$ & Bulk & BETA 206438 (AMS) \\
& 148 & $2190 \pm 40$ & $2226(2113-2332)$ & Bulk & BETA 195416 (AMS) \\
& 184 & $3430 \pm 40$ & $3725(3582-3827)$ & Bulk & BETA 206439 (AMS) \\
& 221 & $3440 \pm 40$ & $3728(3612-3830)$ & Bulk & BETA 202480 (AMS) \\
& 254 & $2600 \pm 40$ & $2540(2508-2786)$ & Bulk & BETA 206440 (AMS) \\
& 292 & $4070 \pm 75$ & $4620(4419-4822)$ & Bulk & BETA 202481 (AMS) \\
& 363 & $2630 \pm 40$ & $2810(2714-2884)$ & Bulk & BETA 206441 (AMS) \\
Nguene-1 (413) & 418 & $3795 \pm 55$ & $4200(3991-4407)$ & Plant macrofossil & GIF 11619 (conv.) \\
& 35 & $430 \pm 40$ & $492(326-536)$ & Bulk & BETA 195415 (AMS) \\
& 75 & $990 \pm 40$ & $845(795-964)$ & Bulk & BETA 195414 (AMS) \\
& 105 & $1630 \pm 40$ & $1512(1410-1615)$ & Bulk & BETA 195413 (AMS) \\
& 125 & $1600 \pm 35$ & $1442(1406-1557)$ & Bulk & GIF 11618 (conv.) \\
& 153 & $1940 \pm 40$ & $1896(1815-1930)$ & Bulk & BETA 202478 (AMS) \\
& 192 & $3310 \pm 40$ & $3526(3449-3636)$ & Bulk & BETA 202479 (AMS) \\
& 257 & $2429 \pm 41$ & $2425(2351-2702)$ & Bulk & UtC 13545 (AMS) \\
& 277 & $2510 \pm 40$ & $2550(2458-2743)$ & Bulk & BETA 206442 (AMS) \\
& 337 & $2540 \pm 40$ & $2720(2488-2750)$ & Bulk & BETA 195412 (AMS) \\
& 375 & $4460 \pm 40$ & $5127(4960-5294)$ & Bulk & BETA 206443 (AMS) \\
& 413 & $4110 \pm 40$ & $4590(4453-4821)$ & Bulk & BETA 189989 (AMS) \\
\hline
\end{tabular}
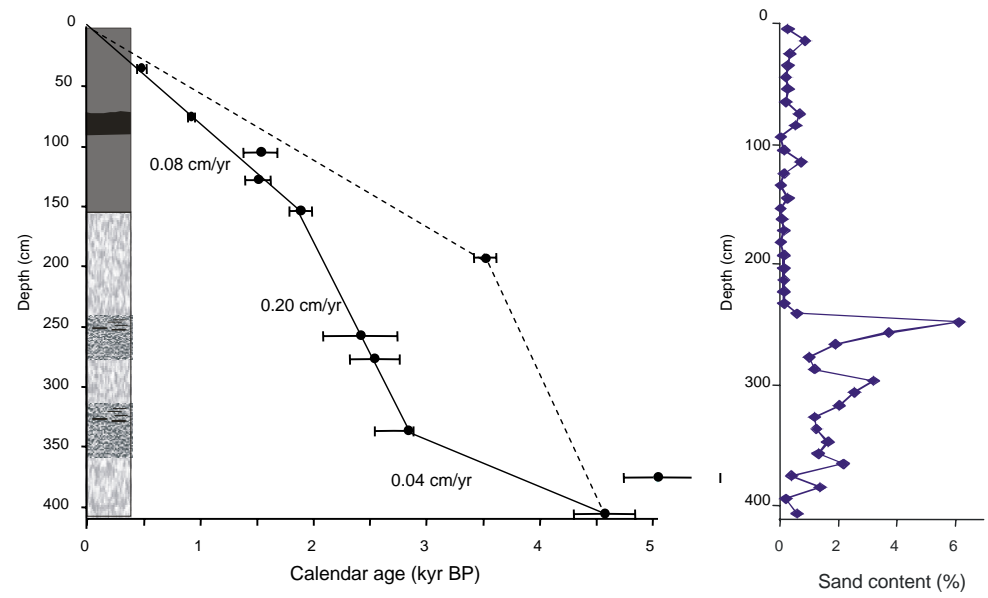

Back, organic-rich clay

Grey clay

Grey, organic-rich gley with numerous plant remains

$\square$ Grey, organic-rich gley

Fig. 2. Age-depth plot and sand content of core NGUE1. The age-model illustrated by the solid line has been used to derive the chronology of the core NGU1. Sediment accumulation rates are based on linear interpolation of calibrated radiocarbon dates.

podzolic horizon, core MAR2 shows a 2 m-thick clayey sand, interspersed by various black organic laminae and some additional sandy layers. Based on the nine radiocarbon dates of the MAR2 core, as well as stratigraphical correlations between the MAR2 and MAR1 cores, two different age-models for the Maridor sediments can be derived. The first chronology (dotted line) shows a single change in the accumulation rate at $97 \mathrm{~cm}$, which is not consistent with the lithology and sand content as these parameters show great variation. These radiocarbon dates, spanning the interval 3500- 


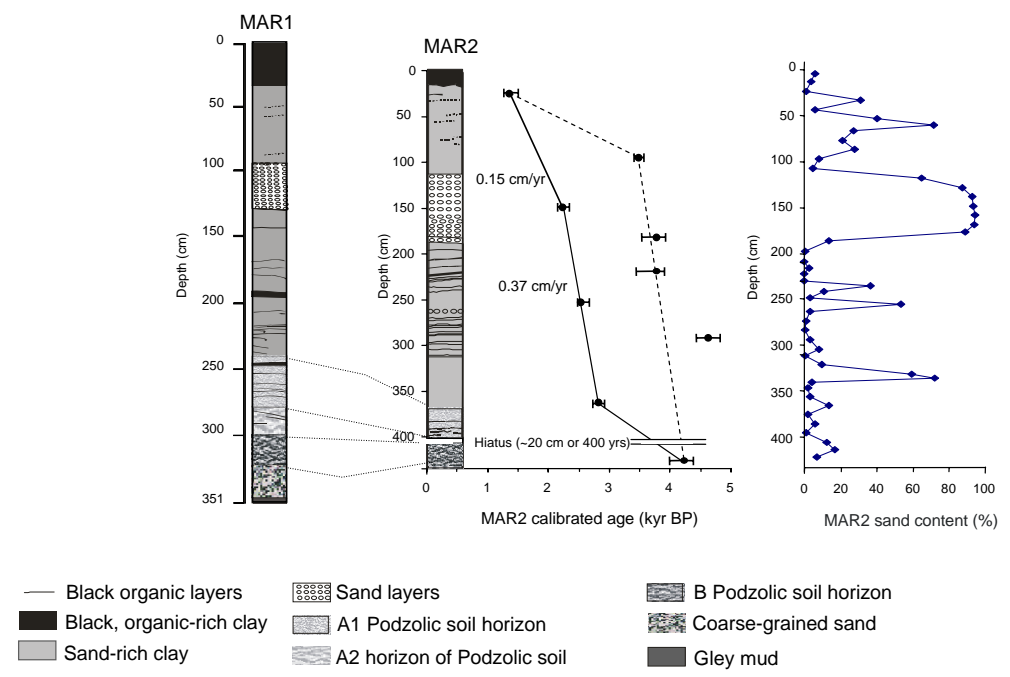

Fig. 3. Age-depth plot and sand content of core MAR2. The age-model illustrated by the solid line has been used to derive the chronology of the core MAR2. Sediment accumulation rates are based on linear interpolation of calibrated radiocarbon dates.

4500 cal yr BP, were obtained from bulk samples of clayey sediments containing black organic-rich layers. This suggests that the organic laminae are mostly allocthonous organic matter originating from the underlying podzolic horizon. The alternative age-model (solid line), constructed using radiocarbon dates, obtained from the non-perturbed clayey sediments and showing more variation, which are either synchronous with increasing sand content or with lithological changes, can be assumed to be closer to reality.

\section{Nguène pollen record}

A total of 121 pollen taxa were identified from the 55 samples of core NGUE1, with changes in the relative pollen abundance clearly reflecting the vegetation dynamics (Fig. 4). Based on floristic changes of the forest component, three pollen zones characterizing the main successive stages have been visually defined.

Zone N3 (ca. 4590-3200 cal yr BP; 413-355 cm) is characterized by high pollen values of the families, Caesalpiniaceae (18-29\%), Mimosaceae (11-18\%) and Sapindaceae (5-16\%). As many of the trees, commonly found in Gabon, belonging to the Caesalpiniaceae (e.g., Monopetalanthus spp., Cynometra spp., Anthonota spp., Berlinia spp., etc.), Mimosaceae (Calpocalyx spp., Piptadeniastrum africana, Pentaclethra spp., etc.) and Sapindaceae (Eriocoelum sp., Chytranthus sp., Ganophyllum sp., etc.), are characteristic of closed canopy rainforest (Aubréville, 1968; Fouilloy and Hallé, 1973; Villiers, 1989), these pollen assemblages indicate that dense stands of mature rainforest occupied the catchment area of Lake Nguène during the mid-Holocene.

However, a slight decline of Caesalpiniaceae pollen between 4100 and 3200 calyr BP (sub-zone N3b: $395-$
$355 \mathrm{~cm}$ ) is associated with high arboreal pollen values of Sapindaceae, indicative of semi-deciduous rainforests (e.g. Ganophyllum sp., Blighia, sp., Chytranthus sp., etc.), as well as with small amounts of Pycnanthus angolensis (Myristicaceae) ( 2\%), Trilepisium madagascariensis (Moraceae) ( 3\%) and Aphania-type (Sapindaceae) ( 3\%) pollen. These latter arboreal pollen taxa, typical of semideciduous rainforest, are light-demanding species growing in old secondary evergreen rainforests. Hence, this pollen assemblage suggests that from $4100 \mathrm{cal}$ yr BP the evergreen rainforest surrounding Lake Nguène was progressively replaced by semi-deciduous rainforest.

Zone N2 (ca. 3200-1400 cal yr BP; 355-115 cm) indicates that major changes occurred in both the marsh and rainforest pollen signal.

Between 3200 and 2400 cal yr BP (subzone N2c: 355$255 \mathrm{~cm}$ ), arboreal pollen taxa characteristic of the mature rainforest are progressively replaced by pioneering plants, notably Alchornea cordifolia (up to 60\%) and Elaeis guineensis $(\sim 10 \%)$, which favour disturbed forest habitats (Maley and Chepstow-Lusty, 2001). In Guineo-Congolian wetlands, Alchornea cordifolia grows in well-drained lake shore soils, as well as open areas of fringing forest bordering the lower reaches of lowland rivers (Lebrun and Gilbert, 1954; Evrard, 1968; Schnell, 1976). This species, which can tolerate marked flooding regimes (Evrard, 1968), may gradually colonize swamp shorelines as the mean water-level lowers. Thus, an abrupt rise in Alchornea cordifolia pollen, following a corresponding decrease in Cyperaceae pollen, clearly indicates that dense stands of littoral vegetation progressively invaded the lake basin. The significant presence of Elaeis guineensis pollen, remaining remarkably constant $(\sim 10 \%)$ throughout zone N2, associated with Tetrorchidium (Euphorbiaceae) pollen $(\sim 3 \%)$ and declining mature forest 


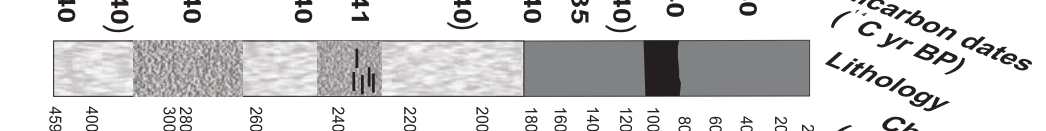

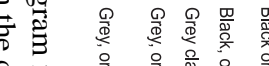
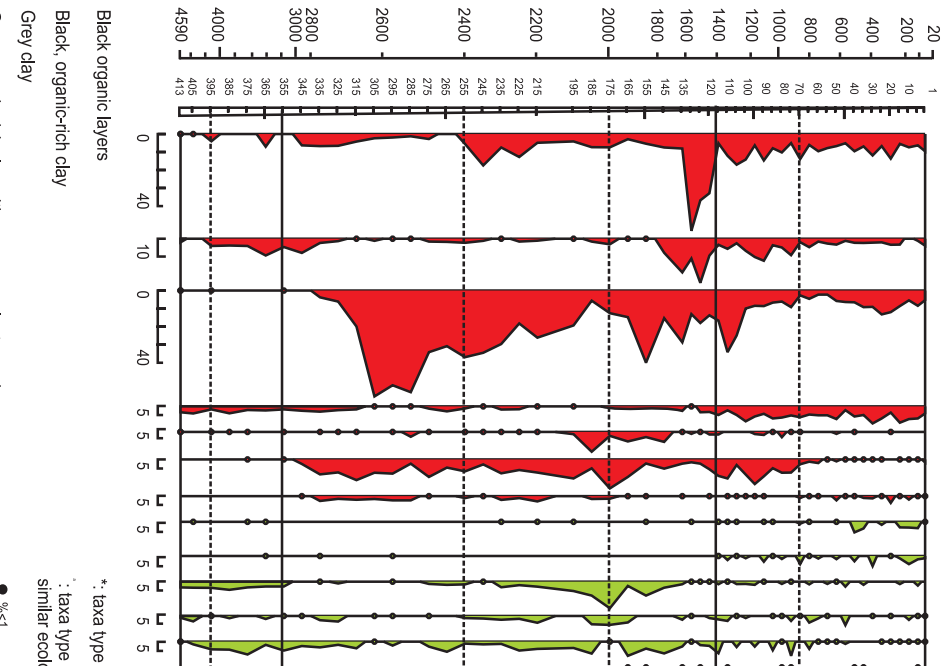

$$
\text { or } 0
$$
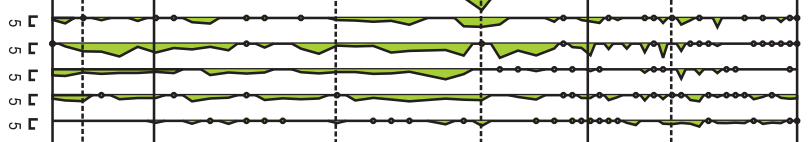

or 5 t
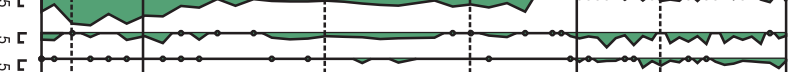

or 5

$\vec{\circ} \mathrm{C}$
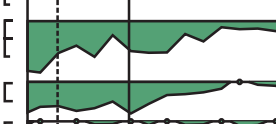

or $[$ to
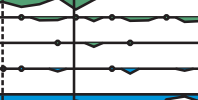

or 5 त 5

or 5

or 5 .

or

E

(1)
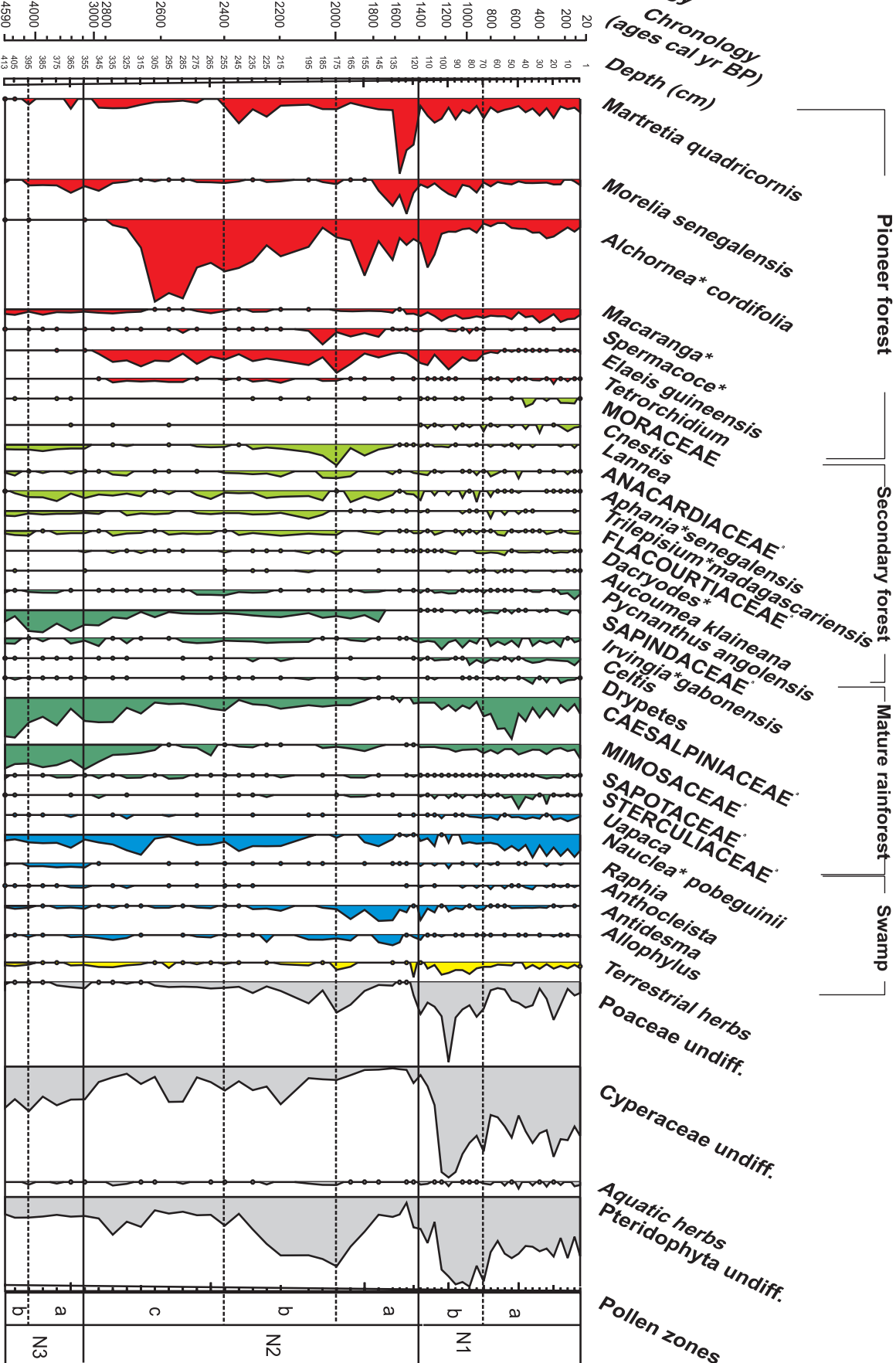

oformat

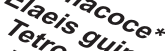

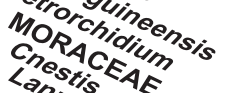

$4 N_{4} e_{2}$

A $4 C_{41}$

NAT

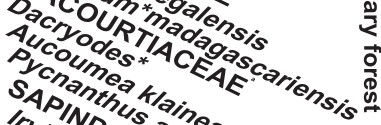

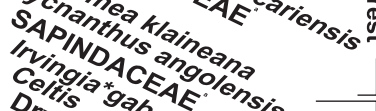

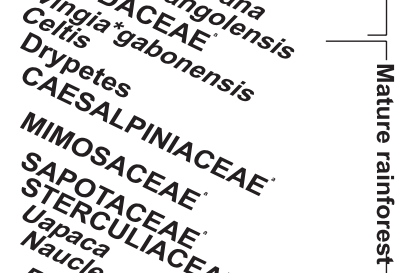

$+$

要 
pollen taxa, indicate the creation of openings in the closed canopy forest surrounding the lake basin.

From 2400 to 2000 calyr BP (sub-zone N2b: 255 $175 \mathrm{~cm}$ ), fern spores and grass pollen markedly increase, reaching maxima of $40 \%$ and $10 \%$ of the total pollen sum, respectively. Many of the marshy pteridophyte species found today around Lake Nguène are either epiphytic ferns in the surrounding Cyperus papyrus swamp, or terrestrial ferns invading the lake shores during dry season low-stands (Ngomanda, personal observation). As fern spores were not identified beyond family level, a distinction was not established between epiphytic wetland and more terrestrial forms. Nevertheless, the rise in fern spores, associated with both a slow increase in grass pollen and declining Cyperaceae pollen abundance, suggests that lake-levels were low during this period. It is also notable that a rise in marshy herbaceous pollen taxa, following a significant decline in Alchornea cordifolia-type pollen, is accompanied by an increasing abundance of secondary forest pollen taxa [e.g., Aphania-type $(\sim 5 \%)$, Lannea-type (Anacardiaceae) (2$15 \%)$, Anacardiaceae ( 5\%), Trilepisium madagascariensis $(\sim 5 \%)$ and Flacourtiaceae $(\sim 3 \%)]$. However, Caesalpiniaceae and Nauclea-type pollen continue to maintain significant relative abundances (5-10\%). This pollen assemblage suggests that a closed canopy rainforest persisted, but with increasing fragmentation allowing secondary forest taxa to colonize the gaps.

Between 2000 and 1400 calyr BP (Zone N2a: 175$115 \mathrm{~cm}$ ) pteridophyte spores decline to $<20 \%$, followed by peaks in the pollen of the riverine species, Alchornea cordifolia (>20\%), Morelia senegalensis (Rubiaceae) $(>15 \%)$ and Martretia quadricornis (Euphorbiaceae) (up to 54\%). Pollen from mature evergreen rainforest taxa, mainly Caesalpiniaceae, as well as those from herbaceous marsh families (i.e. Cyperaceae and Poaceae) are very scarce $(<1 \%)$. In contrast, pollen from secondary forest and semi-deciduous rainforest taxa (e.g. Aphania-type, Lannea, Flacourtiaceae) are significant $(\sim 10 \%)$ This distinct pollen assemblage indicates that maximal regression of the mature evergreen rainforest occurred between 2000 and 1400 cal yr BP, even if the marked alteration in sediments - showing that the grey gley-muds, typical of marshy environments are replaced by fine dark clayey-muds, indicative of lake deposits (Makaya, 2005) suggests that rainfall became abundant.

Zone N1 (ca. 1400-20 cal yr BP; 115-5 cm)

A detailed high-resolution description of this section of the Nguène pollen diagram has been published already (Ngomanda et al., 2007). Here, we sub-divide Zone 1 into two sub-zones to facilitate interpretation.

Between 1400 and 950 calyr BP (subzone N1b: 15$70 \mathrm{~cm}$ ), pollen from herbaceous marsh and swamp tree taxa, particularly Nauclea-type ( $\sim 5 \%)$ and Macaranga-type $(\sim 5-8 \%)$ increase significantly. This indicates that Lake Nguène became a proper lake, which supported both a well-developed swamp forest, dominated by Nauclea-type pobeguinii, as well as an herbaceous marsh. The similar percentages of Cyperaceae pollen and pteridophyte spores (40-50\%) suggest recurring seasonal lake-level fluctuations. Irvingia gabonensis (Irvingiaceae), Caesalpiniaceae and Mimosaceae pollen appear with significant frequencies $(>5 \%)$, while Elaeis guineensis pollen reaches its last high abundance $(10 \%)$, suggesting the end of evergreen rainforest disturbance.

From 950 to 20 cal yr BP (subzone N1a: $70-5 \mathrm{~cm}$ ), Nauclea-type pobeguinii $(5-10 \%$, Mimosaceae (>5\%) and Caesalpiniaceae $(10-25 \%)$ pollen continue to increase, associated with an abrupt decline of Elaeis guineensis pollen $(<1 \%)$. This indicates a renewed spread of dense closed canopy rainforest around the catchment. The associated increase in Nauclea type $(>10 \%)$ and Uapaca type $(\sim 5 \%)$ pollen suggests further expansion of swamp forest and probably higher lake levels.

\section{Maridor pollen record}

A total of 158 pollen and spore taxa were identified in the 58 samples analysed (Fig. 5). Changes in relative pollen abundance in the Maridor record, reflecting the vegetation dynamics, suggest three major zones with a total of four subzones.

Pollen zone M3 (ca. 4265-3940 cal yr BP; 423-405 cm) is dominated by Caesalpiniaceae pollen (16-28\%), an indicator of moist mature evergreen rainforest in the GuineoCongolian region (Aubréville, 1968; White, 1983). Pollen from secondary forest taxa, mainly Aucoumea klaineana, Sacoglottis gabonensis, Lophira alata (Ochnaceae) and Flacourtiaceae are significant ( $>5 \%)$, while pollen of grasses and pioneering shrubs (e.g., Alchornea-type, Macaranga, Tetrorchidium, Elaeis guineensis, etc.) and hygrophytic herbs (Cyperaceae, pteridophytes and aquatics) are scarce $(<1 \%)$. Although Aucoumea klaineana, Sacoglottis gabonensis and Lophira alata are typical secondary forest taxa, they can still be dominant in mature evergreen rainforest (Nicolas, 1977; Caballé and Fontes, 1978). Hence, the pollen assemblage indicates that a closed canopy forest existed in the Maridor region. Evidence of high water levels is provided by Melastomataceae pollen attaining 30\%, which is probably from Dissotis congolensis, a shrub that is found in swampy environments around the lake today (Christy et al., 1990).

Zone M2b (ca. 3460-2890 cal yr BP; 400-370 cm) is characterized by a marked decline in the major closed canopy forest pollen taxa, notably Caesalpiniaceae, Sapindaceae and Mimosaceae, accompanied by a progressive increase in pollen from gap-colonisers [Elaeis guineensis $(\sim 1-50 \%)$, Macaranga (Euphorbiaceae) (5-10\%), Alchornea-type (5$10 \%)$ ], indicating the colonisation of rainforest canopy openings. This rainforest disturbance is concomitant with a significant rise in grass pollen (up to $80 \%$ ) and terrestrial herbaceous pollen $(>15 \%)$, indicating savanna development, 

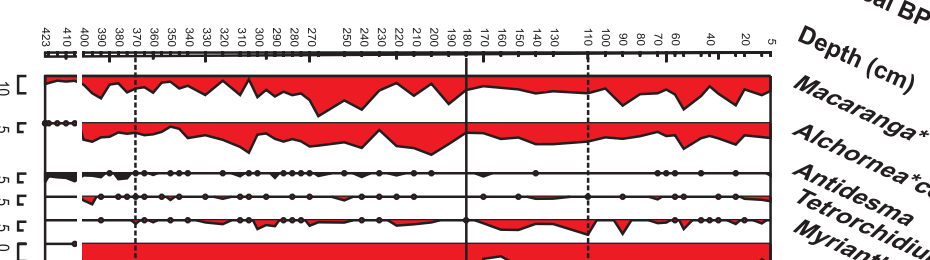

$\vec{a}$

:
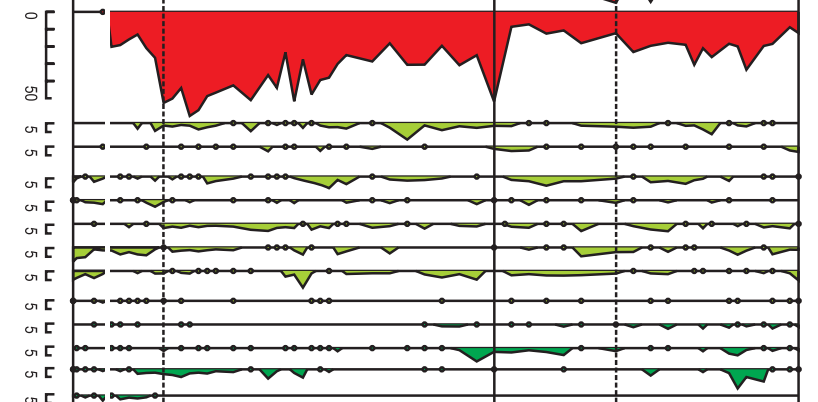

or [

or $[$

or [

or 5
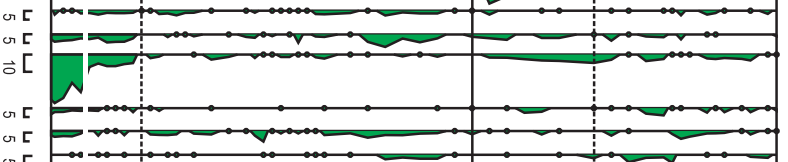

or

or 5
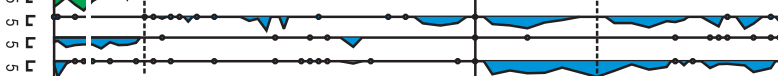

or 5

\&E

E
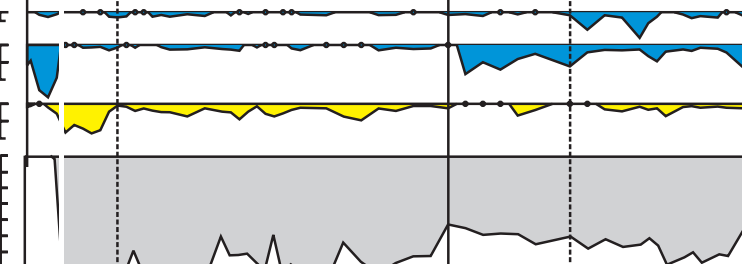

$=$
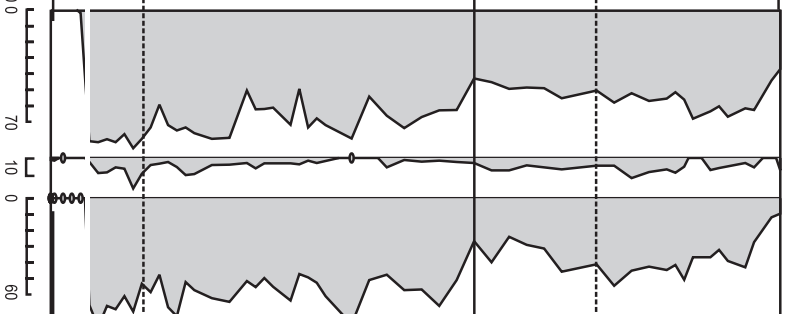

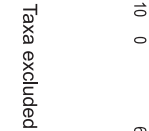
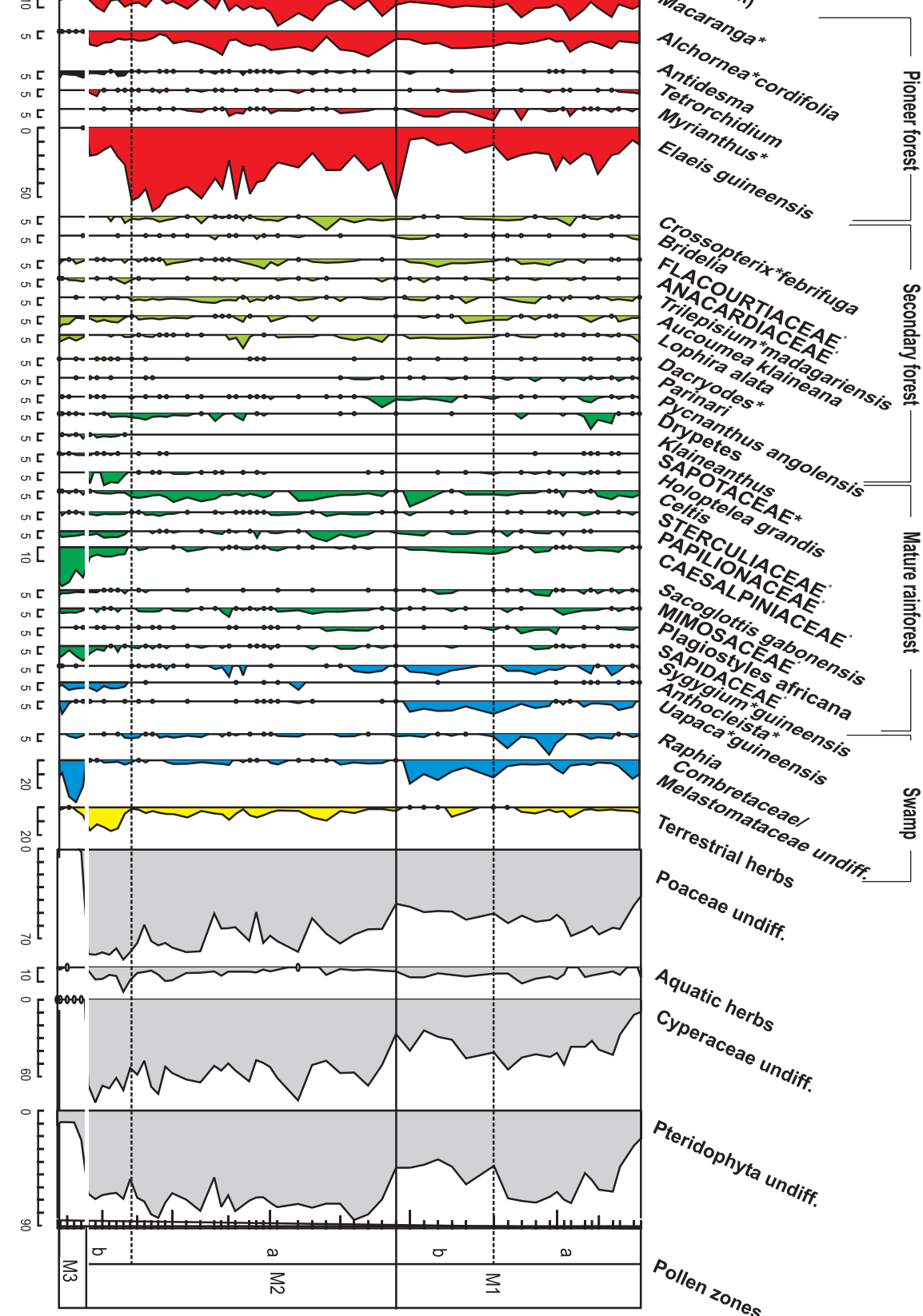

or
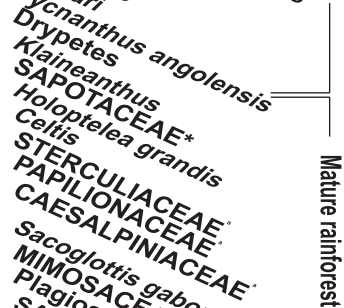
associated with significant peaks of Holoptelea grandis (U1maceae) pollen (up to 10\%). The presence of this deciduous tree (Letouzey, 1968; White, 1983) reinforces the evidence for drier environmental conditions occurring from ca. 3800 cal yr BP.

Zone M2a (ca. 2890-2280 cal yr BP; $370-180 \mathrm{~cm}$ ) is particularly distinguished by a marked increase in pollen from Elaeis guineensis (25-50\%), associated with the continued dominance of other gap-coloniser pollen taxa, Alchorneatype (10-20\%) and Macaranga (10-25\%). An increase in dry conditions is also indicated not only by the notable presence of savanna shrub pollen (such as Crossopterixtype [Rubiaceae]), but even among the mature forest pollen taxa, Celtis (Ulmaceae) pollen (2-7\%) and Sterculiaceae (2$5 \%$ ), both characteristic of semi-deciduous forests (Letouzey, 1968; White, 1983). Cyperaceae pollen (up to 70\%) and pteridophyte spores (up to $80 \%$ ), as well as a decline in aquatic herbs, indicate the development of herbaceous marshy vegetation. This vegetational change coinciding with a lithological shift from podzolic soils to sand-rich clays, suggests that Maridor became a permanent lake.

In zone M1b (ca. 2280-1940 cal yr BP; 180-110 cm) pioneer forest pollen taxa, e.g., Elaeis guineensis (8-12\%) and Macaranga (5-8\%) significantly decline, and there is a marked increase in secondary forest pollen taxa [e.g., Tetracera (Dilleniaceae), Flacourtiaceae, Trilepisium madagascariensis] (Nicolas, 1977; Christy et al., 1990). Concurrently, arboreal pollen taxa from the forest-savanna mosaic (e.g., Lophira alata and Aucoumea klaineana) expand; these species are today actively involved in savanna colonisation in the absence of fire (White and Abernethy, 1997; White et al., 2000; White, 2001). Mature forest trees, mainly Caesalpiniaceae $(\sim 5 \%)$, Mimosaceae $(\sim 5 \%)$ and Celtis $(2-11 \%)$ are also well-represented in the pollen assemblage, indicating that the rainforest was being progressively reconstructed.In addition, pollen from aquatic taxa ( $>5 \%$ of the total pollen sum) increase, associated with the marked rise of Myrianthus (Moraceae) pollen type (>5\%), Uapaca-type (5-10\%) and Melastomataceae (4-17\%) pollen, most probably from the swamp trees present today, Uapaca guineensis and Dissotis congolensis, respectively. The concomitant decline of Cyperaceae pollen and fern spores suggests the significant regrowth of swampy environments around Lake Maridor.

In Sub-Zone Mla (ca. 1940-290 cal yr BP; 110-5 cm), pioneering tree pollen (e.g., Elaeis guineensis and Macaranga) pollen rise again. Although, this is interpreted as an expansion of pioneer forest, it was not associated with a decline of pollen from secondary forest (e.g., Aucoumea klaineana, Tetracera, etc.), swamp forest (Uapaca guineensis, Melastomataceae cf. Dissotis congolensis and Raphia), or mature rainforest (e.g., Drypetes [Euphorbiaceae], Caesalpiniaceae, Mimosaceae, Plagiostyles africana [Euphorbiaceae]) taxa. These pollen assemblages reveal a picture of mixed rainforest types similar to the current complex landscape of forestsavanna mosaic. In addition to the importance of swampy environments around Lake Maridor, the high abundance of Cyperaceae pollen and pteridophyte spores suggest a mosaic of marshy-swampy vegetation.

\section{Discussion}

Pollen data from Lakes Nguène and Maridor clearly show that a well-developed moist rainforest existed around the lakes before $4200 \mathrm{cal}$ yrs BP, as Caesalpiniaceae, a major indicator of Guineo-Congolian moist evergreen rainforest (White, 1983), is abundant in the pollen assemblages. Similar regional vegetation reconstructions have been described from other palaeoecological records across western Equatorial and West tropical Africa. Notably, pollen records from Cameroon (at $\sim 2^{\circ} \mathrm{N}$ ) showed that a Biafrean-type rainforest, dominated by Caesalpiniaceae, existed around Lakes Barombi-Mbo (Maley and Brenac, 1998) and Ossa (Reynaud-Farrera et al., 1996) at that time. During the same period, a semi-evergreen rainforest surrounded the catchment of Lakes Sinnda (Vincens et al., 1998) and Kitina (Elenga et al., 1996) in southern Congo ( at $\left.2^{\circ} \mathrm{S}\right)$, as well as the catchment of Lakes Bosumtwi and Sélé in Ghana and Benin (Salzmann and Hoelzmann, 2005), respectively.

From $4000 \mathrm{cal}$ yr BP, the contraction of moist evergreen rainforest suggests the onset of aridity during the late Holocene. This major vegetation change occurred progressively, first by altering the floristic composition of mature evergreen rainforest (as shown by the replacement of Caesalpiniaceae by semi-deciduous trees), followed by expansion of savannas and/or open forest formations, which reached their maxima between 2700 and $2400 \mathrm{cal} \mathrm{yr} \mathrm{BP.} \mathrm{The}$ opening of the forest and its substitution by savannas and pioneer formations is attested in various late Holocene palaeoecological sites across inter-tropical Africa. Central-East African pollen records clearly show that mountain forest openings occurred synchronously in the highlands of $\mathrm{Bu}-$ rundi, Rwanda and Uganda at 4300,3800 and $2500^{14} \mathrm{C}$ yr BP (Taylor, 1990; Jolly and Bonnefille, 1991; Taylor, 1992, 1993; Jolly et al., 1994, 1997). In West and Central Africa, pollen data suggest a breakdown of African lowland rainforest into two distinct phases: the first one around $4000 \mathrm{cal} \mathrm{yr} \mathrm{BP}$, and a second phase around $2500 \mathrm{cal} \mathrm{yr} \mathrm{BP}$. The first "crisis" impacted the periphery of the central African forest block and was marked by the widespread appearance of savannas. At the northern periphery, at Lac Sélé in Benin, the opening of the "Dahomey Gap", a savanna corridor interrupting the West African rainforest, is dated between 4500 and 3400 cal yr BP (Salzmann and Hoelzmann, 2005). In the south, at Lake Sinnda in southern Congo, the semi-deciduous forest was replaced by savannas after $3990 \pm 700^{14} \mathrm{C}$ yr BP (4530-4400 cal yr BP). This phase of savanna expansion is represented by the lower zone M2 in the Maridor pollen diagram. Sites further within the forest block, such as Lakes Barombi-Mbo and Ossa, the Nyabessan 
swamp (Cameroon), and Lake Kitina (Congo), do not show signs of ecosystem succession for this period, and maintain stable rainforests dominated by Caesalpiniaceae (Elenga et al., 1996; Reynaud-Farrera et al., 1996; Maley and Giresse, 1998; Ngomanda et al., 2009). At these sites, forest opening occurred between 2700 and $2400 \mathrm{cal} \mathrm{yr} \mathrm{BP}$, and is widely considered to have been completed within a few decades (e.g., Maley, 2002, 2004; Ngomanda et al., 2009). This phase of forest breakdown, visible in zone $\mathrm{Ng} 2$ of the Nguène pollen diagram ended around $2000 \mathrm{cal} \mathrm{yr} \mathrm{BP.}$

The spread of savannas in the Maridor region around 4000 cal yr BP, however, occurred as the lake-level increased, as shown both by the sharp rise of pollen from marsh communities, (e.g., Cyperaceae, aquatic herbs) and by the sedimentary changes observed, with the deposition of sandyclays, typical of lake deposits (Giresse et al., 2009), following podzolic soil formation. This latter deposition is typical of lowland areas in the sedimentary sandy basin of coastal Gabon, as well as observed on the Congolese Batéké sands (Schwartz, 1988). Different morphodynamic processes, operating within the lake basin due to climatic oscillations, may explain the apparent contradiction between lake-level fluctuations and vegetation change around Lake Maridor. The sediments at the base of core MAR1, showing gleymuds and podzols, typical of marshy environments, suggest that Lake Maridor was initially a swamp system. Around 4000 cal yr BP, the base of this former swamp acted as a valley bottom; active erosion from the surrounding PlioPleistocene sedimentary basement, and strong stream transport led to accumulation of coarse deposits in the bottom of the swamp. This process is clearly shown by the sedimentary change observed at $\sim 320 \mathrm{~cm}$ in the MAR 1 core, which indicates deposition of coarse-grained sands of alluvial origin. Decreasing water level, due to declining rainfall or more accentuated seasonality, led to subsequent emergence of these coarse alluvial sediments, allowing the development of the podzolic horizon. The accumulation of these podzolised deposits blocked the outflow around $4000 \mathrm{cal} \mathrm{yr} \mathrm{BP}$, facilitating the formation of permanent open water.

It has also been suggested that the major expansion of Elaeis guineensis, coupled with increasing grass cover may be due to human agricultural activity (Sowunmi, 1999), as the recovery of pollen and macro-remains of this oil palm in palaeoecological records has often been used as an anthropogenic indicator (Clist, 1995; Oslisly, 1995, 1998, 2001; Assoko Ndong, 2002). This hypothesis is supported by the fact that in many Neolithic (4500-2500 cal yr BP) and Iron age ( $2400 \mathrm{cal} \mathrm{BP}$ to present) Gabonese archaeological sites, substantial amounts of palm nuts have been recovered, suggesting the importance of this resource to humans during the late Holocene (Clist, 1995; Oslisly, 2001; Assoko Ndong, 2002). However, no evidence for systematic cultivation of Elaeis guineensis in the region has been formerly demonstrated, although the Bantu are considered as farmers; simply gathering palm nuts in secondary forests, natu- rally abundant in E. guineensis, may easily explain its concentration in archaeological sites. Indeed, in other Holocene sites from western equatorial Africa, pollen data clearly show that the expansion of Elaeis guineensis always followed the widespread establishment of grassland savannas (Elenga et al., 1992, 1994) or temporary forest openings (Elenga et al., 1996; Reynaud-Farrera et al., 1996; Maley and Brenac, 1998; Ngomanda et al., 2005). Furthermore, it can be emphasized that the Lake Nguène vegetation record shows a significant decrease in E. guineensis pollen during the last five centuries. This is exactly the time interval when anthropogenic impact on rainforests (e.g., due to increasing human population densities) would be expected to rise.

The rapid ecosystem transition between 4200 and 4000 cal yr BP, from stable moist evergreen forest to drier vegetation formations (i.e. savannas and semi-evergreen forests) and the degradation of rainforest over the third millennium BP, suggest that the vegetation changes observed in Gabon mainly reflect the regional variability of effective moisture. This hypothesis is supported by the records of terrigenous dust deposited in lake sediments downwind from the Sahara, and continental records of past precipitation changes in Central Africa (Nguetsop et al., 2004; Weldeab et al., 2005, 2007). These combined records show a continuous decrease of rainfall from $5200 \mathrm{cal} \mathrm{yr} \mathrm{BP}$ and the appearance of a marked dry season during the Northern Hemisphere winter months with very low atmospheric humidity between 2400 and $2100 \mathrm{cal} y \mathrm{BP}$. The presence in the pollen diagrams of Nguène (e.g. zones N3b and N2) and Maridor (zone M2) of deciduous trees (e.g. Holoptelea grandis, Trilepisium madagascariensis, Celtis sp., Pycnanthus angolensis, Blighia sp., Lannea sp., Aphania senegalensis, Sterculiaceae, etc.) which lose totally or partially their leaves during the Northern Hemisphere winter dry season (Letouzey, 1968; White, 1983) reinforces the evidence for seasonality change occurring from ca. 4000 cal yr BP.

The progressive drying of central African terrestrial ecosystems during the mid- and late-Holocene, which coincided with the desiccation of the Sahara (Kröpelin et al., 2008), is widely thought to have been linked to weaker insolation forcing of the African monsoon and eastern equatorial Atlantic sea-surface temperature anomalies. Furthermore, this would have affected the southward extension of the Intertropical Convergence Zone (ITCZ) and its associated rainfall belt (Nguetsop et al., 2004; Weldeab et al., 2005, 2007; Ngomanda et al., 2009).

\section{Conclusions}

Pollen data from Lakes Maridor and Nguène in Gabon show that hydrological changes occurring over the past $4500 \mathrm{yr}$ were the major driving forces controlling rainforest dynamics in this part of western equatorial Africa. They clearly demonstrate that the current forest-savanna mosaics of the 
coastal region of Gabon began about $4000 \mathrm{cal} \mathrm{yr} \mathrm{BP,} \mathrm{fol-}$ lowing a rapid climatic-induced deterioration of the evergreen rainforest which covered that region during the midHolocene.

Acknowledgements. This study was supported by both the European Development Fund (FED) via the project "Réhabilitation de la Station de Recherche IRET-Makokou/Ipassa Gabon" (CdS No. 005/PSVAP/DP2) and the French project "PRIMUS" (PNEDC). We are grateful to the comments of an anononymous reviewer, L. Dupont and R. Bonnefille which helped us improve the clarity of our manuscript.

Edited by: R. Bonnefille

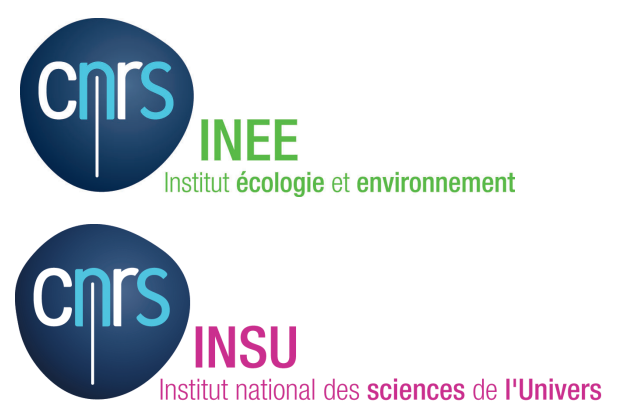

Publication of this paper was granted by EDD (Environnement, Développement Durable) and INSU (Institut des Sciences de l'Univers) at CNRS.

\section{References}

Assemien, P., Bonnefille, R., Cambon-Bou, G., Caratini, C., Cerceau, M. T., Dang, C. D., Fredoux, A., Guers, J., Guinet, P., Hideux, M., Hul-Thol, S., Keddam-Malplanche, M., Le Thomas, A., Lobreau-Callen, D., Lugardon, B., Maley, J., Mallea, M., Masure, E., Medus, J., Nigaud, M., Riollet, G., Senesse, S., Sivak, J., Soler, M., Stainier, F., Thanikaimoni, G., and Thiam, A.: Pollen et Spores d'Afrique tropicale, Travaux et Document de Géographie Tropicale, Association des Palynologue de Langue Française, Bordeaux, 1974.

Assoko Ndong, A.: Synthèse des données archaeologiques récentes sur le peuplement à l'Holocène récent de la réserve de faune de la Lopé, Gabon, L'Anthropologie, 106, 135-158, 2002.

Aubréville, A.: Les étranges mosaïques forêt-savanes du sommet de la boucle de l'Ogooué au Gabon, Adansonia, 7(1), 13-22, 1967.

Aubréville, A.: Flore du Gabon: Légumineuses-Caesalpinioidées, Muséum National d'Histoire Naturelle, Paris, 361 pp., 1968.

Bonnefille, R. and Riollet, G.: Pollens des savanes d'Afrique orientale, CNRS, Paris, 130 pp., 1980.

Caballé, G. and Fontes, J.: Les inventaires forestiers au gabon, application à la phytogéographie, Bois et Forêts des Tropiques, 177, 15-33, 1978.

Christy, P., Moungazi, A., and Wilks, C.: Etude environnementale de la zone d'Oyane pour Sun Gabon Oil Company, Africa Forest, Libreville, 45 pp., 1990.

Clist, B.: Gabon: 100000 ans d'Histoire, Centre Culturel Français Saint-Exupery (Gabon), Libreville, 376 pp., 1995.
Elenga, H., Schwartz, D., and Vincens, A.: Changements climatiques et action anthropique sur le littoral congolais au cours de l'Holocène, B. Soc. Geol. Fr., 163, 239-252, 1992.

Elenga, H., Schwartz, D., and Vincens, A.: Pollen evidence of Late Quaternary vegetation and inferred climate changes in Congo, Palaeogeogr. Palaeocl., 109, 345-356, 1994.

Elenga, H., Schwartz, D., Vincens, A., Bertaux, J., de Namur, C., Martin, L., Wirrmann, D., and Servant, M.: Diagramme pollinique holocène du Lac Kitina (Congo): mise en évidence de changements paléobotaniques et paléoclimatiques dans le massif forestier du Mayombe, CR. Acad. Sci. II A, 323, 345-356, 1996.

Evrard, C.: Recherches écologiques sur les peuplements forestiers des sols hydromorphes de la Cuvette centrale congolaise, Série Scientifique, Publ. I.N.E.A.C, Bruxelles, 1968.

Faegri, K. and Iversen, J.: Text Book of Modern Pollen Analysis, IV, John Wiley and Sons Ltd., Chichester, 1989.

Fontes, J.: Les formations herbeuses du Gabon, Annales de l'Université nationale du Gabon, 2, 126-153, 1978.

Fouilloy, R. and Hallé, N.: Flore du Gabon: Sapindaceae, Muséum National d'Histoire Naturelle, Paris, 202 pp., 1973.

Giresse, P., Makaya, M., Maley, J., and Ngomanda, A.: Late Holocene equatorial environments inferred from deposition processes, carbon isotope of organic matter, and pollen in three shallow lakes of Gabon, west-central Africa, J. Paleolimnol., 41, 369-392, 2009.

Giresse, P., Maley, J., and Brenac, P.: Late Quaternary palaeonvironments in Lake Barombi Mbo (West Cameroon) deduced from pollen and carbon isotopes of organic matter, Palaeogeogr. Palaeocl., 107, 65-78, 1994.

Giresse, P., Maley, J., and Kossoni, A.: Sedimentary environmental changes and millennial climatic variability in a tropical shallow lake (Lake Ossa, Cameroon) during the Holocene, Palaeogeogr. Palaeocl., 218, 257-285, 2005.

Jolly, D. and Bonnefille, R.: Diagramme pollinique d'un sondage Holocene de la Kuruyange (Burundi, Afrique Centrale), Palaeoeco. A., 22, 519-529, 1991.

Jolly, D., Bonnefille, R., and Roux, M.: Numeritical interpretation of high resolution Holocene pollen record from Burundi, Palaeogeogr. Palaeocl., 109, 357-370, 1994.

Jolly, D., Taylor, D., Marchant, R., Hamilton, A.Bonnefille, R., Buchet, G., and Riollet, G.: Vegetation dynamics in central Africa since 18,000 yr BP: pollen records from the interlacustrine highlands of Burundi, Rwanda and Western Uganda, J. Biogeogr., 24, 495-512, 1997.

King, J., Moutsinga, J.-B., and Doufoulon, G.: Conversion of anthropogenic savanna to production foret through fire-protection of forest-savanna edge in Gabon, Central Africa, Forest Ecol. Manag., 94, 233-247, 1997.

Kröpelin, S., Verschuren, D., Lezine, A.-M., Eggermont, H., Cocquyt, C., Francus, P., Cazet, J.-P., Fagot, M., Rumes, D., Russell, J. M., Darius, F., Conley, D. J., Schuster, M., von Suchodoletz, H., and Engstrom, D. R.: Climate-driven ecosystem succession in the Sahara: the past 6000 years, Science, 320, 765-768, 2008.

Lebrun, J. and Gilbert, G.: Une classification écologique des forêts du Congo, Publ. I.N.E.A.C, Bruxelles, 1954.

Leroux, M.: Le climat de l'Afrique tropicale, Champion, Paris, 633 pp., 1983.

Letouzey, R.: Etude Phytogéographique du Cameroun, Encyclopédie Biologique, Paul Lechevallier, Paris, 511 pp., 1968. 
Makaya, M.: Les paléoenvironnments sédimentaires fini-holocènes de trois lacs du Gabon (Kamalété, Nguène et Maridor). Etude sédimentologique et biogéochimique, unpublished Ph.D.thesis, Université de Perpignan, France, 2005.

Maley, J.: A catastrophic destruction of African forests about 2500 years ago still exerts a major influence on present vegetation formations, IDS Bull-I. Dev. Stud., 33, 13-30, 2002.

Maley, J.: Les variations de la végétation et des paléoenvironnements du domaine forestier africain au cours du Quaternaire récent, in: Évolution de la végétation depuis deux millions d'années, Artcom, Errance, Paris, 143-178, 2004.

Maley, J. and Brenac, P.: Vegetation dynamics, paleoenvironments and climatic changes in the forests of western Cameroon during the last 28000 years BP, Rev. Palaeobot. Palyno., 99, 157-187, 1998.

Maley, J. and Chepstow-Lusty, A.: Elaeis guineensis Jacq. (oil palm) fluctuations in central Africa during the late Holocene: climate or human driving forces for this pioneering species?, Veg. Hist. Archaeobot., 10, 117-120, 2001.

Maley, J. and Giresse, P.: Etude d'un niveau argileux organique du Mayombe (Congo occidental) riche en pollen d'Elaeis guineensis et daté d'environ 2800 ans BP. Implications pour les paléoenvironnements de l'Afrique Centrale., in: Géosciences au Cameroun, Presse Universitaire du Cameroun, Yaoundé, 77-84, 1998.

Ngomanda, A., Chepstow-Lusty, A., Makaya, M., Schevin, P., Maley, J., Fontugne, M., Oslisly, R., Rabenkogo, N., and Jolly, D.: Vegetation Changes during the past 1300 years in Western Equatorial Africa: a high-resolution pollen record from Lake Kamalété, Lopé Reserve, Central Gabon, Holocene, 15, 1021-1031, 2005.

Ngomanda, A., Jolly, D., Bentaleb, I., Chepstow-Lusty, A., Makaya, M., Maley, J., Fontugne, M., Oslisly, R., and Rabenkogo, N.: Response of African lowland rainforest to hydrological balance changes during the past 1500 years in Gabon, Western Equatorial Africa., Quaternary Res., 67, 411-425, 2007.

Ngomanda, A., Neumann, K., Schweizer, A., and Maley, J.: Seasonality change and the third millennium BP rainforest crisis in southern Cameroon (Central Africa), Quaternary Res., 71, 307$318,2009$.

Nguetsop, V. F., Servant-Vildary, S., and Servant, M.: Late Holocene climatic changes in West Africa, a high resolution diatom record from equatorial Cameroon, Quaternary Sci. Rev., 23, 591-609, 2004.

Nicolas, P.: Contribution à l'Etude Phytogéographique de la Forêt du Gabon. Unpublished Ph.D.thesis, Université Paris I, France, 1977.

Oslisly, R.: The middle Ogooué valley, Gabon: cultural changes and palaeoclimatic implications of the last four millennia, Azania, XXIX-XX, 324-331, 1995.

Oslisly, R.: Hommes et milieux à l'Holocène dans la moyenne vallée de l'Ogooué (Gabon), B. Soc. Geol. Fr., 95(1), 93-105, 1998.

Oslisly, R.: The History of Human Settlement in the Middle Ogooué Valley (Gabon), in: African Rain Forest Ecology and Conservation, Yale University Press, New Haven and London, 101-118, 2001.

Reimer, P. J., Baillie, M. G. L., Bard, E., Bayliss, A., Beck, J. W., Bertrand, C. J. H., Blackwell, P. G., Buck, C. E., Burr, G.
S., Cutler, K. B., Damon, P. E., Edwards, R. L., Fairbanks, R. G., Friedrich, M., Guilderson, T. P., Hogg, A. G., Hughen, K. A., Kromer, B., McCormac, G., Manning, S., Ramsey, C. B., Reimer, R. W., Remmele, S., Southon, J. R., Stuiver, M., Talamo, S., Taylor, F. W., van der Plicht, J., and Weyhenmeyer, C. E.: INTCAL04 Terrestrial Radiocarbon age calibration, 026 cal Kyr BP, Radiocarbon, 46, 1029-1058, 2004.

Reynaud-Farrera, I., Maley, J., and Wirrmann, D.: Végétation et climat dans les forêts du Sud-Ouest Cameroun depuis 4770 ans B.P: analyse pollinique des sédiments du Lac Ossa, CR. Acad. Sci. II A, 322, 749-755, 1996.

Salzmann, U. and Hoelzmann, P.: The Dahomey Gap: an abrupt climatically induced rain forest fragmentation in West Africa during the late Holocene, Holocene, 15, 190-199, 2005.

Schnell, R.: Introduction à la phytogéographie des pays tropicaux. La flore et la végétation de l'Afrique tropicale, Gauthier-Villars, Paris, 1976.

Schwartz, D.: Some podzols on Bateke sands and their origins, People's Republic of Congo, Geoderma, 43, 229-247, 1988.

Schwartz, D.: Assèchement climatique vers 3000 B.P. et expansion Bantu en Afrique Centrale atlantique: quelques réflexions, B. Soc. Geol. Fr., 163(3), 353-361, 1992.

Sosef, M. S.: Refuge Begonias; taxonomy, phylogeny and historical biogeography of Begonia sect. Loasibegonia and sect. Scutobegonia in relation to glacial rain forest refuges in Africa, Wageningen Agric. Univ. Papers, 1994.

Sowunmi, M. A.: The significance of the oil palm (Elaeis guineensis Jacq.) in the late Holocene environments of west and west central Africa: a further consideration, Veg. Hist. Archaeobot., 8, 199-210, 1999.

Taylor, D.: Late Quaternary pollen records from two Ugandan mires: evidence for environmental change in the Rukiga Highlands of southwest Uganda, Palaeogeogr. Palaeocl., 80, 283-300, 1990.

Taylor, D. M.: Pollen evidence from Muchoya swamp, Rukiga Highlands (Uganda), for abrupt changes in vegetation during the last 21000 years, B. Soc. Geol. Fr., 163, 77-82, 1992.

Taylor, D. M.: Environnemental change in montane southwest Uganda: a pollen record for the Holocene from Ahakagyezi swamp, Holocene, 3(4), 324-332, 1993.

Villiers, J.-F.: Flore du Gabon: Leguminosae-Mimosoideae, Muséum National d'Histoire Naturelle, Paris, 1989.

Vincens, A., Schwartz, D., Bertaux, J., Elenga, H., and de Namur, C.: Late Holocene climatic changes in Western Equatorial Africa inferred from pollen from Lake Sinnda, Southern Congo, Quaternary Res., 50, 34-45, 1998.

Weldeab, S., Kölling, M., and Wefer, G.: Holocene African droughts related to eastern equatorial Atlantic cooling, Geology, 33, 981-984, 2005.

Weldeab, S., Lea, D. W., Schneider, R., and Andersen, N.: 155000 years of West African Monsoon and Ocean thermal evolution, Science, 316, 1303-1307, 2007.

White, F.: Vegetation of Africa, UNESCO/AETFAT/UNSO Maps and Memoirs, Paris, 1983.

White, L. J. T.: Vegetation history and logging disturbance: effects on rain forest mammals, in the Lopé Reserve, Gabon (with special emphasis on Elephants and Apes), unpublished Ph.D.thesis, University of Edinburgh, 1992.

White, L. J. T.: Forest-Savanna dynamics and the origins of Maran- 
taceae forest in central Gabon, in: African Rain Forest Ecology and Conservation, Yale University Press, New Haven and London, 165-182, 2001.

White, L. J. T. and Abernethy, K.: A Guide to the Vegetation of the Lopé Reserve Gabon, ECOFAC GABON, Libreville, 1997.

White, L. J. T., Oslisly, R., Abernethy, K., and Maley, J.: L'Okoumé (Aucoumea klaineana): expansion et déclin d'un arbre pionnier en Afrique centrale atlantique au cours de l'Holocène, in: Dynamique à long terme des écosystèmes forestiers intertropicaux, Mémoire UNESCO, Paris, 399-411, 2000.
Wirrmann, D., Bertaux, J., and Kossoni, A.: Late Holocene paleoclimatic changes in Western Central Africa inferred from mineral abundance in dated sediments from Lake Ossa (Southwest Cameroon), Quaternary Res., 56, 275-287, 2001.

Ybert, J.-P.: Atlas de pollens de Côte d'Ivoire, InitiationsDocumentations Techniques, ORSTOM, Paris, 1979. 